\title{
The Anthropocene as a regime of visibility: the posthumanist paradox between domination and liberation
}

\author{
O Antropoceno como regime de visibilidade: o paradoxo pós- \\ humanista entre dominação e libertação
}

\section{Alice Dal Gobbo ${ }^{1}$}

Emanuele Leonardi²

\begin{abstract}
The discourse of the 'Anthropocene' has quickly become pervasive, cross-cutting different fields of knowledge. However, it is also a deeply contested category. In the critical light shed by political ecology, we reflect on the conceptual blindspots that mark its narrative, identifying it as a symptom of a broader impasse of the neoliberal governmentality of nature and of the ecological crisis today. On the one hand, the Anthropocene narrative proposes a post-humanist vision, which potentially decentres anthropocentrism. On the other hand, this same vision becomes an alibi for ever deeper and less reflective interventions of human beings on the biosphere, in particular through technoscientific developments. This paradox responds to a specific need for capitalist valorization of 'Nature' and, at the same time, does not seem capable to elaborate solutions to the ecological crisis as a whole. However, if the Anthropocene becomes visible only in the present historical contingency and due to specific kinds of knowledge, we suggest that reflecting on epistemological issues is key to the search for more ecological ways of situating in the world. Which forms of knowledge allow us to understand the emancipatory potential of posthumanism within the Anthropocene while avoiding new predatory effects on the biosphere?
\end{abstract}

Keywords: Anthropocene posthumanism neoliberalism value knowledge.

\footnotetext{
${ }^{1}$ University of Trento, Department of Sociology and Social Research.

2 University of Parma, Department of Humanities, Social Sciences and Cultural Industries.

E-mail: lele.leonardi@gmail.com
} 


\section{Resumo}

O discurso do Antropoceno rapidamente se infiltrou por todo o lado, atravessando diferentes áreas do conhecimento. Contudo, também é uma categoria altamente contestada. À luz da crítica proveniente da ecologia política, refletimos sobre os pontos cegos conceituais que marcam a sua narrativa, identificando-a como um sintoma de um impasse mais alargado da governamentalidade neoliberal da natureza e da crise ecológica atual. Por um lado, a narrativa do Antropoceno propõe uma visão pós-humanista, a qual potencialmente descentra o Antropocentrismo. Por outro lado, esta mesma visão se torna um álibi para intervenções mais profundas e menos refletidas dos seres humanos na biosfera, em particular através de desenvolvimentos tecno-científicos. Este paradoxo responde a uma necessidade específica da valorização capitalista da 'Natureza' e, ao mesmo tempo, não parece ser capaz de elaborar soluções para a crise ecológica como um todo. Contudo, se o Antropoceno se torna visível apenas na presente contingência histórica e devido a tipos específicos de conhecimento, sugerimos que refletir sobre questões epistemológicas é a chave para a busca de modos mais ecológicos de nos situarmos no mundo. Que formas de conhecimento nos permitem compreender o potencial emancipatório do pós-humanismo no interior do Antropoceno, ao mesmo tempo que evitamos novos efeitos predatórios sobre a biosfera?

Palavras-chave: Antropoceno pós-humanismo neoliberalismo valor conhecimento.

\section{Introduction}

Anthropocene: the term has become popular both in academic discourse and in mainstream media - even in the communicative spaces of everyday life. The word emerged within the 'hard sciences', tied to a desire to make of our present time a new geological era, defined by the impact of human activities. However, the concept has quickly gained interest and space in the political, sociological and ecological debate. Its problematique calls into question the very ways in which contemporaneity expresses itself. Moreover, it immediately intersects the increasingly disruptive ecological crisis, our knowledge about it and, finally, the constructive, re-constructive, adaptive and transformative practices that are going 
to be ever more necessary in the decades to come3. That the Anthropocene is being simultaneously studied from different perspectives; that research questions (and answers) from extremely diverse disciplines intertwine in a hitherto unusual way; these two aspects by themselves point to the peculiar character of this literally epochal 'discovery'. The matter is at the very same time chemical, geological, political, literary, sociological, artistic: this fact alone suggests the impossibility of thinking the evolution of the biosphere as separate and separable from human society, history, culture. Diverse layers of socio-ecological existence are better understood as co-emergent: such frameworks, in facts, opens up a space for redefining the human with respect to the non-human, pushing the intellectual debate towards post-humanist perspectives that promote a decentralization of essentialist visions of 'humanity'. Instead, the what should be highlighted is the inherent relationality of biological existence, the constant hybridizations between human bodies and technology, the inseparability of social and ecological organization 4 .

On the other hand, the proliferation of interrogations on, and with, the Anthropocene seems to suggest the need for a constant unravelling: looking for its knots, its dark sides, its unspoken elements. This is not just a speculative task: rather, it carries a practical urgency and a sense of necessity quite unique in human history. The stakes are very concrete: the survival of life as we know it on the planet. In this discursive proliferation, the issue of knowledge appears to be central5, since it is through a number of different scientific/cultural dispositifs that the Anthropocene' gets articulated. This suggests that it might be more useful to think of it not so much as a factual reality but rather as a discursive construction that, as such, entails both material and political effects. In what follows, we start from a review of the Anthropocene discourse; subsequently, we interrogate the process of its emergence: which problematizations, visibility regimes, power/knowledge

\footnotetext{
3 LATOUR, Bruno; STENGERS, Isabelle; TSING, Anna; BUBANDT. Anthropologists Are Talking About Capitalism, Ecology, and Apocalypse. Ethnos 83, no. 3 (27 May 2018): 587-606. https://doi.org/10.1080/o0141844.2018.1457703.

4 HARAWAY, Donna. Staying with the Trouble: Making Kin in the Chthulucene. Durham: Duke University Press, 2016; MARCHESINI, Roberto. Il tramonto dell'uomo: la prospettiva postumanista. EDIZIONI DEDALO, 2009; BRAIDOTTI, Rosi. The Ethics of Becoming Imperceptible. In BOUNDAS, Constantin (Org). Deleuze and Philosophy. Edinburgh: Edinburgh University Press, 2006, p. 133-59.

5 EDWARDS, Paul. Knowledge Infrastructures for the Anthropocene. The Anthropocene Review 4, no. 1 (April 2017): 34-43. https://doi.org/10.1177/2053019616679854.
} 
apparatuses do feed into it 6 ? We argue for the importance of situating the the Anthropocene within the larger critique of the political economy/ecology of capitalism. In doing so, we disclose the space for a different - utterly political understanding of human embeddedness into natural processes.

\section{The symptom-Anthropocene and its paradox}

In the examination of the discursive, scientific and political construction of the Anthropocene one can notice a singular paradox. The new geological era is defined as the one in which the human being becomes uniquely 'visible' in the configuration of the biophysical environment. In this sense, it becomes a geological agent among others, albeit particularly crucial7. This recognition is potentially of great significance since, by saying that the human being is a geological agent, the natural sciences 'discover' a positionality that the human being has denied him/herself for centuries: to be $a$ natural force among many others ${ }^{8}$. This seems to put into question the narrative of human exceptionalism which, especially since modernity, has justified the domination of nature by positing Man (white, male, heterosexual) as clearly separate from (and superior to) what he calls 'Nature'9. In the Anthropocene, the human being is immersed, interrelated, dynamically coemerging with the biosphere and this 'coming together' materialises as peculiar geological concretion, layer of rock, $\mathrm{CO}_{2}$ concentration. So, while Man imagined himself [sic] at the height of his control of Nature through modern techno-scientific apparatuses, his agency is decentred; it becomes all the more clear that domination jeopardizes, rather then enhancing, earthly survival. This has the potential to undermine anthropocentrism, questioning the capacity for control, reflexivity, intentionality and deliberation that have marked narrations of progress and development in recent centuries ${ }^{10}$.

\footnotetext{
${ }^{6}$ FOUCAULT, Michel. Power/Knowledge: Selected Interviews and Other Writings 1972-1977. Harlow: Pearson Education Limited, 1980.

7 GAFFNEY, Owen; STEFFEN, Will. The Anthropocene Equation. The Anthropocene Review 4, no. 1 (April 2017): 53-61. https://doi.org/10.1177/2053019616688022.

8 Albeit the denial of Man's [sic] positionality does not apply to Western knowledge as a whole, as for instance in the case of late ' 800 s geographical debate in the USA. See: TORRE, Salvo. Carl Ortwin Sauer, Un segmento ingenuo di realtà. Acireale-Roma: Bonanno, 2007.

9 BARCA, Stefania. L'Antropocene: Una Narrazione Politica. Riflessioni Sistemiche 17 (2017): 56-67. ${ }^{10}$ VIGNOLA, Paolo. Figli Di Un Antropocene Minore. Il «popolo a Venire» Come Individuazione Ecologica Collettiva. In PELGREFFI, Igor (Org.). Ecologia. Teoria, Natura, Politica. Tricase: Kaiak Edizioni, 2018, p. 87-101.
} 
However, the discourse of the Anthropocene is simultaneously inhabited by narratives that little have to do with a de-centring of the human. In its official version, the catastrophic effects of modern capitalist exploitation of the biosphere operated via science and technology are in hindsight a further proof of the power of the Human: s/he is indeed so powerful to be able to alter Earth balances. According to this view, the recognition that humanity is part of nature does not lead to a humble and self-limiting approach to planetary ecologies. Rather, based on assumed human power to shape ecosystems, the response to crisis is more technique, more science: more deployment of this formidable power. In this way, agency, power and control of Man are re-established right on the verge of their dawn ${ }^{11}$. This is the blindspot of the Anthropocene and the reason why, we argue, it does not allow to trace forms of socio-ecological organization beyond domination, capable of care and repair with (not on) the earth. Furthermore, such a blindspot pushes us to identify in the Anthropocene a symptom of a historical era to be criticized and overcome ${ }^{12}$.

\section{Cognitive capitalism and neoliberal governmentality: under what conditions can the Anthropocene be seen?}

The symptomatological framework we just outlined clearly shows that the discussion concerning the origin of the Anthropocene does not solely concern geology, but rather (and perhaps above all) politics. In every definition, in every periodization two different and tensive elements coexist: the scientific need for classification (through a series of consistent selection criteria) and the irreducibly political dynamic that innervates different styles of governmentality. As pointed out by Mariaenrica Giannuzzi ${ }^{13}$, every founding myth expresses a situated and nonneutral interpretation of the interaction between human species, global environment and capitalism as a mode of production. For example, in the Braudelian periodization proposed by Jason W. Moore and corroborated by Simon

\footnotetext{
${ }^{11}$ PELLIZZONI, Luigi. Intensifying Embroilments: Technosciences, Imaginaries and Publics. Public Understanding of Science 26, no. 2 (2017): 212-19.

${ }^{12}$ LEONARDI, Emanuele; BARBERO, Alessandro. Introduzione - Il Sintomo-Antropocene'. In MOORE, Jason. Antropocene o Capitalocene? Scenari Di Ecologia-Mondo Nell'era Della Crisi Planetaria. Verona: Ombre Corte, 2017.

${ }^{13}$ GIANNUZZI, Mariaenrica. Antropop: not sad philosophies for thinking about climate change, in Effimera.org, $2015 \quad$ [http://effimera.org/anthropop-filosofie-non-tristi-per-pensare-ilcambiamento-climatico-di-mariaenrica-giannuzzi/] [last accessed 5 June 2019]
} 
Lewis and Mark Maslin ${ }^{14}$, the Anthropocene begins in the long sixteenth century and is thus constitutively based on the Cartesian dualism that opposes nature and society. In the 'industrialist' view suggested by the Andreas Malm and Alf Hornborg15, the Anthropocene begins in 1874, with the steam engine and is thus based on the coal-driven Industrial Revolution. This is, however, a controversial subject as it is not immune from technocratic temptations such as those expressed by Paul Crutzen ${ }^{16}$. Finally, the globalization-focused understanding advanced among others by Will Steffen and John McNeill ${ }^{17}$ states that the Anthropocene begins after World War II with the Great Acceleration and thus indicates in the economic trend, both Fordist and neoliberal, the main driver ecologically harmful expansion.

Each of these three positions has advantages and disadvantages, which attract a good part of the interpretative efforts made in the debate. For the purposes of this article, however, we would like to pose a different question: not so much when the new era begins; rather, when it began to be seen as such. In fact, regardless of the option chosen, there is unanimous agreement that the problematic conveyed by the notion of Anthropocene emerged at the end of the $1980 \mathrm{~s}^{18}$, and

\footnotetext{
14 LEWIS, Simon; MASLIN, Mark. Defining the Anthropocene. Nature, 519, 171-180, 2015. According to Lewis and Maslin the origin of the Anthropocene should coincide with the Orbis spike [from the Latin term for "world"], that is with the drastic reduction in the concentration of carbon dioxide in the atmosphere (with a record low in the year 1610) due to the so-called "Columbian Exchange". By this term is meant the exchange and the profound mixture of plant and animal organisms - but also of objects and ideas - between the eastern and western hemispheres. It is undoubtedly an ecological phenomenon of fundamental importance that takes its name from Columbus, whose first expedition to the Americas in 1492 paved the way for an era increasing contacts on a large scale between the Old and the New World. From a biological point of view, the most relevant outcome of this exchange was the globalization of food: corn and potatoes traveled from America to Europe, Asia and Africa, wheat and cane sugar instead went the opposite way. Same thing with regard to the import by the New World of pets - horses, cows, goats and pigs. The end result was a radical reorganization of the life on Earth, unprecedented from a geological point of view. The tragic implication of this process was the genocide of the native population of the Americas: Lewis and Maslin estimate that it has passed, due to disease, wars, enslavement and famines - all brought by Europeans - from around 6o million in 1492 to around 6 million in 1650. The immediate consequences of this genocide - almost complete disappearance of agriculture and semi-cessation in the use of fire - involved the regeneration of about 50 million hectares of forests, wooded savannahs and grasslands, which produced an enormous absorption of carbon dioxide through plants and soils, therefore enacting an impressive lowering of emissions into the atmosphere.

15 MALM, Andreas; HORNBORG, Alf. A Geology of Mankind? A Critique of the Anthropocene Narrative. The Anthropocene Review, 1, 1, 2014, pp. 62-69.

${ }^{16}$ CRUTZEN, Paul. Albed Enhancement by Stratospheric Sulfur Injections: a Contribution to Resolve a Policy Dilemma?. Climate Change, 77, 2006, pp. 211-220.

${ }^{17}$ STEFFEN, Will; GRINEVALD, Jacques; CRUTZEN, Paul; McNEILL, John. The Anthropocene: Conceptual and historical perspectives. Philosophical Transactions of the Royal Society, 369, 2011, pp. 842-867.

${ }^{18}$ CHAKRABARTY, Dipesh. The Climate of History: Four Theses. Critical Inquiry, 35, 2009, 197222.
} 
subsequently became more and more pressing - up to the absolute urgency it nowadays requires. Let us ask this question having in mind, as methodological references, both the centrality placed by Foucault on the relationship between power and visibility ${ }^{19}$, and the Marxian indication that it is the anatomy of man that explains that of the ape, not vice versa $a^{20}$ - which in our reasoning means that it is neoliberal governmentality that explains the Anthropocene, not vice versa. To grasp the regime of visibility that builds the Anthropocene as a geological phenomenon which is also relevant for politics, it is first of all necessary to point out its differences compared to the previous regime. Since the ecological crisis is at stake, a materialist perspective should start from the value-nature nexus, that is, from the relationship that political economy establishes between the environment/biosphere on the one hand, and the accumulation of capital in its historical development on the other. According to classical economists, the relationship between nature and value is established as follows: the former acts as an unaccounted for resource - infinite and free, in the Ricardo's words - both at the beginning of the process (raw materials for production) and at the end of the process (disposal of waste). In this model, the environment is configured as abstract social nature, to recall Moore's apt wording, which is to say as a condition for value-creation. Instead, the source of value is abstract social labor, i.e. human working capacity as organized by capital through the wage-form. It is worth re-emphasizing the need for this ecological visibility regime that the environment/biosphere is transformed through abstraction into an infinite and free resource: it is on this the basis, in fact, that the paradigm of production for production's sake was able to establish itself as a reasonable political goal, and that subsequently economic growth could establish itself as panacea for all evil, regardless of its social destination (Keynesian welfare up to the 1970s, corporate absolutism in recent decades).

Similarly, it shouldn't be difficult to see the direct link between the expansionism of the productive sphere and the explosion of the ecological crisis between the late 1960 s and the early $1970 .^{21}$ It is clear that this frame of reference has profoundly changed today. And it is not by chance that, although known since

\footnotetext{
19 CATUCCI, Stefano. Potere e visibilità. Studi su Michel Foucault. Macerata: Quodlibet, 2019. ${ }^{20}$ MARX, Karl. Introduzione alla critica dell'economia politica (1857), tr. it. Macerata: Quodlibet, 2010.

${ }^{21}$ LEONARDI, Emanuele. Lavoro Natura Valore. André Gorz tra marxismo e decrescita. NapoliSalerno: Orthotes, 2017.
} 


\section{8 | Dossiê - Natureza e Sociedade no Antropoceno - Superando a Separação?}

the XIX Century, climate change has become a public problem, a politically visible question only in the late 1980 s, that is, when the neoliberal rationality has allowed us to see a developmental strategy for capital within the 'crisis of reproduction' (i.e.: ecological) created by capital itself. Since then - since the elites can claim that global warming is a market failure (in that it was unable to internalize environmental costs) which, however, can only be solved by another wave of marketization (carbon trading and other forms of commodification of nature) - the Anthropocene could finally become the horizon of 'sustainable' accumulation. This is a major politicalepistemic mutation, encapsulated in formulas such as sustainable development and green economy, which we think can be explained on the basis of the transformation of the value-nature nexus described above. In fact, it no longer occurs in the classic form of the subordination of the reproductive sphere to the productive one (the former infinite and free, the latter finite and paid for), but also in the new guise of cognitive capitalism ${ }^{22}$. In this context some elements of social reproduction, mixed with cognitive labor and therefore subjected to exploitation, end up becoming direct elements of valorization. This is not surprising if we consider the fundamental role played by digital computation in producing data and simulations concerning global warming. As shown by historian Paul Edwards ${ }^{23}$, no one goes through a planetary atmospheric experience without the support of climate science. In order for a link to be established between a weather event - no matter how extreme - and global warming, there is a need for large-scale mobilization of the general intellect in its various forms (i.e. knowledge factories: universities, think tanks, counterarguments by social movements, etc.). Obviously such a dependence on knowledge in no way reduces the concrete materiality of climate change conditions, neither with regard to the identification of their multiple causes, nor with reference to their destructive effects. However, what should be emphasized is that, in Matteo Pasquinelli's words, "the political perception of the Anthropocene is possible only due to a global network (apparently neutral) of sensors, data centers, supercomputers and scientific institutions" 24 .

But if the Anthropocene is a performativity that would not exist without the

\footnotetext{
${ }^{22}$ LEONARDI, Emanuele. Bringing Class Back In. Ecological Economics, 156: 83-90, 2019.

23 EDWARDS, Paul. A Vast Machine. Cambridge MA: MIT Press, 2010.

24 PASQUINELLI, M. The Eye of the Algorithm: Cognitive Anthropocene and the Making of the World Brain,

2014

[https://www.academia.edu/8751480/The_Eye_of_the_Algorithm_Anthropocene_and_the_Ma

king_of_the_World_Brai n] [last accessed 31 May 2019]
} 
cognitive work that (re)produces it, its symptomatic character pushes us even further in the socio-historical and political analysis of its appearance. Going back to the Foucaultian commitment to investigate knowledge as strictly cognate and interconnected with power, one thus asks: what kind of power lays at the basis of the emergence and proliferation of the Anthropocene narrative? Further, in a more historical-materialist vein, how does this cor-respond to the specific forms that relations of (value) production take in the present? As already hinted at above, both the existence and the 'success' of the Anthropocene as discourse go hand in hand with new emerging dynamics of capitalist valorization. These, in turn, are inseparable from the neoliberal governmentality of nature and the processes of neoliberalization that have invested the biosphere and the human communities inhabiting it since the 1970 s $^{25}$. One of their dogmas is that the so-called 'free market', once it subordinates the entire production process to itself, is capable of self-regulating and thus produces optimal effects for all stakeholders. This dogma is directly relevant to the ecological crisis and its governance, since it promotes the elimination of all non-economic barriers to the valorization of nature. The belief is that inclusion of so-called 'natural resources' and biospheric reproductive capabilities within the formal economy may salvage them from the overexploitation that they suffer: by giving them a fair price, they are endowed with value, hence, they are no longer to be considered 'free and unlimited'. But this shift in the labor-nature-value nexus does not mitigate environmental damage: it is functional to relaunching valorization processes partly halted by the crisis of the 1970s. On the one hand, it de-regulates the space of economic action on 'nature' by untying it from the social and political constraints of collective deliberation; on the other hand, it opens up new frontiers of subsumption of the biosphere under capital, as in the case of the 'green economy'26.

A change in ontological and epistemological categories emerges at this juncture, characterized by the blurring of boundaries between human and nonhuman, generative power of reason and of matter, etc. The move beyond the rigid distinction between Humanity and Nature opens up the horizon of capitalist

\footnotetext{
25 BLOK, Andreas; BRUUN-JENSEN. The Anthropocene event in social theory: On ways of problematizing nonhuman materiality differently. The Sociological Review. 1- 17, 2019; HEYNEN, Nick; McCARTHY, James; PRUDHA, Scott; ROBBINS, Paul. (orgs.) Neoliberal Environments: False promises and unnatural consequences, London: Routledge, 2007.

${ }^{26}$ CASTREE, Noel. Neoliberalism and the Biophysical Environment 1: What 'Neoliberalism' Is, and What Difference Nature Makes to it. Geography Compass, 2010.
} 


\section{0 | Dossiê - Natureza e Sociedade no Antropoceno - Superando a Separação?}

valorization processes: it inaugurates a certain neoliberal post-humanism in which 'nature' no longer exists independently of human beings but, rather, opens to technoscientific processes that inform and give shape to it ${ }^{27}$. The narrative of the Anthropocene and its symptomatic paradox are enablers and intensifiers of neoliberal governmentality. In this context, saying that the human being is a geological agent capable of changing the historical evolution of the planet reinforces the con-fusion of nature and society and this justifies ever more daring experiments and manipulations of human, more-than-human, trans-human assemblages. This is the root of the 'dark side' of the Anthropocene: that post-humanism is bent to the imperative of value production and capitalist accumulation. New ontoepistemologies become part and parcel of the dominative project of capital, driven by its 'will to power'. So, despite post-humanism has the potential to de-centre the human towards a newfound humility in front of the rest of nature ${ }^{28}$, forces that negate this opportunity surreptitiously re-emerge.

A key concept in neoliberal governmentality, responsibility, demonstrates this quite clearly 29. In the Anthropocene narrative, in fact, responses to the ecological crisis are framed in terms of (self)-control of the individual, of Humanity, of technoscience. Since these subjects are invoked as responsible for environmental degradation, there is an implicit assumption that they are also able to 'fix' this precisely by taking responsibility. They are to rationally evaluate actions, choose the course of events, measure and predict so as to better direct them in desired ways. Again, planetary destinies are left to the choices and actions of the same subjects

\footnotetext{
${ }_{27}$ PELLIZZONI, Luigi. Ontological Politics in a Disposable World. The new Mastery of nature. Farnham: Ashgate, 2015.

${ }^{28}$ As for instance in the debate ascribable to the Feminist New Materialisms, see for example: COOLE, Diane; FROST, Samantha (orgs.). New Materialisms: Ontology, Agency, and Politics. Durham: Duke University Press, 2010.

29 The rhetoric of responsibilization manifests itself on several levels. For example, the individual citizen is asked to engage in 'responsible consumption', something that moralises people's practices without questioning the wider context in which they articulate (see for example SPAARGAREN, Gert; OOSTERVEER, Peter. Citizen-consumers as agents of change in globalizing modernity: The case of sustainable consumption. Sustainability, 2, 1887-1908, 2010). Humanity as a whole is itself called upon to take responsibility for the ecological crisis that it has itself produced, to 'save the planet' by changing the consumerist model that it is supposed to have uncritically and wholly embraced. To technoscience is asked to be 'responsible' while doing innovation and research, taking into account starting conditions and its own effects on the world, as with Responsible Research and Innovation (RRI) (see for example: DI GIULIO, Gabriella; GROVES, Cristopher; MONTEIRO, Marko; TADDEI, Renzo. Communicating through vulnerability: knowledge politics, inclusion and responsiveness in responsible research and innovation. Journal of Responsible Innovation, 92-109, 2016). For further critical perspectives, see: LUKE, Timothy. Ecocritique: Contesting the Politics of Nature, Economy, and Culture. Minneapolis: University of Minnesota Press, 1999.
} 
who produced the crisis, still represented as sovereign, capable of shaping naturein-becoming thanks to their power. This move promotes and justifies a specific politics of nature and the body, where manipulation becomes functional to particular projects of domination. Simultaneously, this process is quite literally 'naturalized': since humans are part of nature, it is just normal that they mould it to their will. The depoliticizing effects of the Anthropocene dispositive are thus evident. First, stating that it is 'natural' for human beings to mould and assemble with non-humans leaves aside the question of how this interaction happens, what are its underlying logics and effects. Hence, capitalist 'will to power' is reinforced and justified as a mere (post)human tendency.

Secondly, as a sovereign kind of responsibility is attributed to certain subjects (individuals, scientists, Humanity as such), a de-contextualized freedom to choose and act is assumed, which again underestimates the extent to which actions, beliefs, choices, material cultures and intellectual debates themselves emerge within fields of antagonistic and unequal forces. Human beings move in an environment that is largely determined, whose semiotic-material assemblages are established, made of inter-dependencies in which science and technology are fully implicated 30 . Attributing the responsibility for change to the individual means that such structuring of the world is not questioned: the architecture of the choice environment, the social construction of subjectivity and desire ${ }^{31}$. To attribute responsibility for the ecological crisis to a generic Humanity, seen as a homogeneous entity, has the effect of hiding how capitalism has bent the entire globe to the interests of a minority of white men, through diverse forms of imperialism (including an ecological one) ${ }^{32}$. The expansion of Western industrial and consumerist organization of life, to which ecosystem degradation is attributed, is thus constructed as a neutral and simply accepted process, desired and happily embraced by the whole planet. On the contrary, it has been a violent process which has annihilated sometimes very strong resistances - but this remains hidden. Likewise, to talk about 'responsible' technoscientific innovation promotes the

\footnotetext{
$3^{3}$ HARAWAY, Donna. Staying with the Trouble: Making Kin in the Chthulucene. Durham: Duke University Press, 2016

${ }^{31}$ SHOVE, Elizabeth; WALKER, Gordon. Governing transitions in the sustainability of everyday life. Research Policy, 39, 471- 476, 2010; DAL GOBBO. Un desiderio moralizzato, una vita contabilizzata: sull'ecologia vista dal punto di vista del Voluntary Human Extinction Movement, in: Effimera.org, http://effimera.org/un-desiderio-moralizzato-vita-contabilizzata-sullecologia-vista-dal-puntovista-del-voluntary-human-extinction-movement/ [last accessed 29/10/2020].

32 BARCA, Stefania. Forces of Reproduction. Cambridge: Cambridge University Press, 2020.
} 


\section{2 | Dossiê - Natureza e Sociedade no Antropoceno - Superando a}

Separação?

illusion that this sphere might self-regulate independently from economic-political agendas and from collective debate about its broader aims and socio-ecological implications.

In sum, we might say that the Anthropocene paradox responds (at least in part) to the neoliberal paradox. On the one hand, there is a tension towards a total deregulation of the economic sphere, left free to infiltrate any life space and vital process. This tends towards a posthumanist 'dissolution' of the rigid dichotomy between society and nature, human work and biological processes. On the other hand, and simultaneously, neoliberal politics of nature cannot do without the exceptionalism of a dominative subject, holding a position of supremacy and control. This would imply the dissolution of 'capital'. In fact, despite its increasingly de-personalized character, capital needs the 'territory' of some kind of sovereignty that embodies property, extracts surplus labour and value, accumulates profits. In so far as the Anthropocene as dispositive of the crisis is not capable (or willing) of addressing the political economy/ecology of capitalism, its post-humanist implications will remain open and prone to subsumption to projects of domination. At this point, the question emerges: Is the Anthropocene a suitable narrative to face the crisis we are experiencing? Or does it need to be dropped in favor of different, more emancipatory discourses?

\section{Conclusions. Re-thinking the Earth}

We started from the observation that the Anthropocene, as a dispositif, shows a paradoxical character: on the one hand, it makes the human being completely immanent to the evolutionary processes of the biosphere, de-centering it within the web of life, stressing its co-dependencies; on the other hand, the dominant narrative re-establishes the centrality of the human, its power to control and transform the biosphere. We have suggested that the Anthropocene, more than a given reality, is the result of a performative narrative: it exists within a truthdiscourse, which in turn depends on particular devices, such as cognitive labor. As such, it is intimately linked to apparatuses of power/knowledge and to the historical problematizations they embody - specifically, those concerning the neoliberalization of nature. To this embeddedness we have attributed the two-fold, apparently conflicting character of the Anthropocene. On the one hand, the post- 
humanist (partial) adaptation to a neoliberal politics of nature that tends to remove barriers to economic valorization. So, for instance, just as 'nature' is internalized in the economy as a productive factor, the neat nature-civilization dichotomy decays and/or becomes fluid. On the other hand, the post-humanism thus inaugurated by neoliberal governmentality cannot completely dismiss the human being (as white, male, owner) whose interests it bears. For this reason, its discourse sees the reemergence of a Humanity responsible for planetary destinies: armed with the same techno-scientific tools that brought it to the border of self-destruction, just at the moment in which it was under the illusion of having 'conquered the world'. That the Anthropocene uses the rhetoric of Humanity or the human race as a whole, on its part, has the function of depoliticizing the crisis and the ways to address it, perpetuating the neoliberal order as natural and essential.

Given the profoundly problematic character of the Anthropocene discourse, many authors have proposed to use, in its place, terms such as Capitalocene, Plantatiocene, Chtulucene, Era of Gaia and so on33. However, perhaps the point is not so much to dismiss this name as to politicize its narrative. Overcoming the Cartesian dichotomy between Civilization/Humanity and Nature (and related: human and non-human, mind and body, thought and matter, etc.) can be conceived as a positive moment of emancipation from the devices of power/knowledge that informed domination on Earth throughout modernity. On the other hand, what we have called neoliberal post-humanism, while (at least apparently) overcoming this dichotomy, does not seem to have emancipatory effects: on the contrary, it intensifies the range of action of the human being on the rest of the biosphere, releasing it more and more from any kind of limit. The argument proposed in this article highlights a crucial aspect of the post-Cartesian ontology that characterizes neoliberalism: it needs to surreptitiously reintroduce a dominant subject who becomes vehicle for the processes of capitalist accumulation.

Certainly, it is important to be wary of epistemological and ontological approaches that embrace the post-human without problematizing its historical contingent materialization; yet, this does not mean that post-humanist epistemologies must be rejected tout court. Instead, starting from a critical genealogy of the categories of the present, it might be productive to identify the nodes where dynamics of domination, subjugation, exploitation are grafted. An 
14 | Dossiê - Natureza e Sociedade no Antropoceno - Superando a Separação?

onto-epistemology that deals with the inevitable co-emergence and coconstitutiveness of human and non-human existence, if it is not to fall into the neoliberal trap of unlimited valorization, should simultaneously critically interrogate the emergence of more-than-human, concrete and contextual concatenations, and the political economy/ecology of contemporary capitalism. The task is to bring humans and non-humans together on the common ground of a liberated life, subtracted from the imperatives of capitalist valorization, just as the forms of knowledge that interrogate their co-beingness.

Recebido em: 19/11/2020. Aprovado em: 01/12/2020. Publicado em: 26/12/2020. 